\title{
Effects of Dietary Methionine, Taurine, Cystine and Glycine on Liver and Serum Lipids in Rats Fed with a Histidine-excess Diet
}

\author{
Eri OHmura, Tomohiro IshiKawa, Mika TaKagi, \\ Yoritaka AOYAma and Akira Yoshida \\ Laboratory of Nutritional Biochemistry, Department of Agricultural Chemistry, \\ School of Agriculture, Nagoya University, Furo-cho, Chikusa-ku, \\ Nagoya 464, Japan \\ Received November 13, 1987
}

\begin{abstract}
Feeding with a $3.5 \%$ histidine diet caused hypercholesterolemia, hepatomegaly and decreased lipid content in the liver of rats. The addition of $1.0 \% \mathrm{~L}$-methionine to the $3.5 \%$ histidine diet caused increases in liver lipids and serum total cholesterol as compared with those in rats fed with the $3.5 \%$ histidine diet. The addition of $1.0 \% \mathrm{~L}$-cystine to the $3.5 \%$ histidine diet caused an increase in serum total cholesterol compared with that in rats fed with the 3.5\% histidine diet, but the addition of taurine had no effect on serum and liver lipids. The addition of $2.5 \%$ or $5.0 \%$ glycine to the $3.5 \%$ histidine diet decreased serum total and HDL cholesterol compared with that in rats fed with the $3.5 \%$ histidine diet.
\end{abstract}

It is known that serum cholesterol is affected by dietary supplemenation of several amino acids. Taurine, one of the sulfur-containing amino acids had a lowering effect on serum cholesterol when it was added to a cholesterol diet. ${ }^{1,2)}$ Glycine 'supplementation ameliorated casein-induced hypercholesterolemia in rabbits and rats, ${ }^{3)}$ while more than $3.5 \%$ Lhistidine supplementation to a basal diet induced hypercholesterolemia in rats $^{4,5}$ and this hypercholesterolemia developed endogenously. ${ }^{6,7)}$ In the present study, we used histidine-induced hypercholesterolemia as a model of endogenous hypercholesterolemia. Although the effect of several amino acids on hypercholesterolemia caused by cholesterol feeding has been well examined, there are few studies that used endogenous hypercholesterolemia. So we examined the effect of taurine and glycine on serum and liver cholesterol in rats fed with a histidine-excess diet. It is known that L-methionine and L-cystine are metabolized to taurine in liver, ${ }^{8)}$ so we also examined the effect of methionine and cystine as to whether these amino acids have a similar effect to taurine in rats fed with the histidine-excess diet.

\section{MATERIALS AND METHODS}

Animals and diets. Male rats of the Wistar strain (Shizuoka Laboratory Animal Center, Hamamatsu, Japan) were housed individually in screen-bottomed cages in an air-conditioned room at a temperature of $23 \pm 2^{\circ} \mathrm{C}$, with a $12 \mathrm{hr}$ cycle of light $(0800 \sim 2000 \mathrm{hr})$ and dark. The rats were allowed free access to food and water. The composition of the experimental diets is shown in Table I. All rats were fed with a basal diet for $3 \sim 5$ days prior to feeding with the experimental diets, which were administered for 10 days. Dietary changes in the content of $L$ histidine, L-methionine, glycine, L-cystine and taurine were compensated for by adjusting the amount of carbohydrates. At the end of the feeding period, the rats were fasted for $4 \mathrm{hr}$, anesthestized with diethyl ether and sacrificed at $1300 \mathrm{hr}$ within a short period. Blood was removed by cardiac puncture, and the livers were removed and weighed.

Analytical methods. Liver lipids were extracted and purified by the method of Folch et al..$^{9}$ and the liver lipid content was gravimetrically estimated after removing the solvent. Liver cholesterol, serum total and HDLcholesterol were measured by the $o$-phthalaldehyde method, ${ }^{10}$ serum HDL-cholesterol being separated by the method of Noma et al. ${ }^{11}$

Statistical analysis. A statistical analysis of differences 
TABle I. COMPosition OF THE ExPERIMENTAL Diets

\begin{tabular}{lcc}
\hline Ingredient & $\begin{array}{c}\text { Basal } \\
\text { diet }\end{array}$ & $\begin{array}{c}3.5 \% \text { His } \\
\text { diet }\end{array}$ \\
\hline Casein $^{a}$ & $25 \%$ & $(\%)$ \\
L-Histidine $^{b}$ & 0 & 25 \\
Corn oil $^{c}$ & 5 & 3.5 \\
Vitamin mixture $^{d}$ & 0.85 & 5 \\
Choline chloride $^{a}$ & 0.15 & 0.15 \\
Mineral mixture $^{e}$ & 3.5 & 3.5 \\
Sucrose $^{f}$ & 21.8 & 20.7 \\
Starch $^{g}$ & 43.7 & 41.3 \\
\hline Retinyl palmitate $^{h}$ & $0.27 \mathrm{mg} / 100 \mathrm{~g}$ of diet \\
Ergocalciferol $^{h}$ & $2.5 \mu \mathrm{g} / 100 \mathrm{~g}$ of diet \\
dl- $\alpha$-Tocopheryl acetate $^{h}$ & $10 \mathrm{mg} / 100 \mathrm{~g}$ of diet
\end{tabular}

a Katayama Chemical Industries Co., Ltd., Osaka, Japan.

b Ajinomoto Co., Inc., Tokyo, Japan.

c Nihon Shokuhin Kako Co., Ltd., Fuji, Shizuoka, Japan.

d For details, see Y. Aoyama, H. Yasui and K. Ashida, J. Nutr., 101, 739 (1971).

- AIN-76 ${ }^{\mathrm{TM}}$ mineral mixture. For details, see American Institute of Nutrition, J. Nutr., 107, 1340 (1977).

$f$ Taiyo Co., Ltd., Tokyo, Japan.

$g$ Corn, Chuo Shokuryo Co., Ltd., Inazawa, Aichi, Japan.

${ }^{h}$ Eizai Co., Ltd., Tokyo, Japan.

among values was analyzed by Duncan's multiple range test $^{12)}$ and Student's $t$-test. ${ }^{13)}$

\section{RESULTS}

\section{Experiment 1}

The effect of adding methionine to a basal or a $3.5 \%$ histidine-diet on body weight gain, liver weight, and on the levels of total liver lipids, liver cholesterol, serum total cholesterol and serum HDL-cholesterol in the rats is summarized in Table II. The addition of methionine to the basal diet caused no significant changes in body weight gain, liver weight and liver and serum lipids levels, except for the HDL-cholesterol level. The rats fed with the $3.5 \%$ histidine diet with methionine showed lower body weight gain than the rats fed with the $3.5 \%$ histidine diet without methionine. Liver in the rats fed with the $3.5 \%$ histidine diet was significantly higher than that in the rats fed with the basal diet. Total liver lipids and the liver cholesterol content in rats fed with the $3.5 \%$ histidine diet was lower than those in rats fed with the basal diet. Liver lipids content was increased by the addition of methionine to the $3.5 \%$ histidine diet. Serum total cholesterol level in the rats fed with the $3.5 \%$ histidine diet was higher than that in the rats fed with the basal diet. Methionine added to the $3.5 \%$ histidine diet caused a further increase in the total serum cholesterol level.

\section{Experiment 2}

The effect of adding taurine or cystine to the basal or to the $3.5 \%$ histidine diet on body weight gain, liver weight, and on the levels of total liver lipids, liver cholesterol, total serum cholesterol and serum HDL-cholesterol in the rats is summarized in Table III. The addition of taurine or cystine to the basal diet caused a decrease in the liver cholesterol content. Hepatomegaly was caused by adding cystine to the basal diet. The addition of either taurine or cystine to the $3.5 \%$ histidine diet did not affect body weight gain. The liver weight in rats fed with the $3.5 \%$ histidine diet was greater than that in rats fed with the basal diet. There was no effect from the addition of taurine or cystine to the $3.5 \%$ histidine diet on liver weight. The total liver lipids content in rats fed with the $3.5 \%$ histidine diet was significantly lower than those in rats fed with the basal diet. There was no effect from the addition of taurine or cystine to the $3.5 \%$ histidine diet on the total liver lipids content. The liver cholesterol level in rats fed with the $3.5 \%$ histidine diet was not significantly different from that in rats fed with the basal diet. The liver cholesterol level was not affected by the addition of taurine or cystine to the $3.5 \%$ histidine diet, as compared with that in rats fed with the $3.5 \%$ histidine diet. Serum total cholesterol and HDL-cholesterol levels in rats fed with the $3.5 \%$ histidine diet were significantly higher than those in rats fed with the basal diet. The addition of taurine to the $3.5 \%$ histidine diet did not affect the serum cholesterol level, although the addition of $1.0 \%$ cystine to the 
Table II. Effect of the Addition of Methionine to a Basal or a 3.5\% Histidine Diet on Body Weight Gain, Liver Weight, Total Liver Lipids, Liver Cholesterol, Serum Total AND HDL ChOLESTERol in RATS (EXPERIMENT 1) ${ }^{1}$

\begin{tabular}{ccccccc}
\hline Diet & $\begin{array}{c}\text { Body weight } \\
\text { gain } \\
(\mathrm{g} / 10 \mathrm{days})\end{array}$ & $\begin{array}{c}\text { Liver weight } \\
(\mathrm{g} / 100 \mathrm{~g} \mathrm{BW})\end{array}$ & $\begin{array}{c}\text { Total liver } \\
\text { lipids } \\
(\mathrm{mg} / \mathrm{g})\end{array}$ & $\begin{array}{c}\text { Liver } \\
\text { cholesterol } \\
(\mathrm{mg} / \mathrm{g})\end{array}$ & $\begin{array}{c}\text { Serum total } \\
\text { cholesterol } \\
(\mathrm{mg} / 100 \mathrm{ml})\end{array}$ & $\begin{array}{c}\text { Serum HDL } \\
\text { cholesterol } \\
(\mathrm{mg} / 100 \mathrm{ml})\end{array}$ \\
\hline Basal & $39.3 \pm 2.5^{2}$ & $4.87 \pm 0.11$ & $56.2 \pm 3.8$ & $2.77 \pm 0.05$ & $118.6 \pm 5.0$ & $61.7 \pm 3.0$ \\
Basal $+1.0 \%$ Met & $34.1 \pm 2.1$ & $5.04 \pm 0.17$ & $63.6 \pm 4.8$ & $2.79 \pm 0.04$ & $126.5 \pm 3.8$ & $74.2 \pm 3.7^{*}$ \\
\hline Basal & $41.7 \pm 1.8^{\mathrm{a} 3}$ & $4.54 \pm 0.11^{\mathrm{b}}$ & $55.1 \pm 3.4^{\mathrm{a}}$ & $2.90 \pm 0.09^{\mathrm{a}}$ & $128.7 \pm 6.3^{\mathrm{c}}$ & $70.6 \pm 7.4^{\mathrm{b}}$ \\
$3.5 \%$ His & $40.2 \pm 0.8^{\mathrm{a}}$ & $5.86 \pm 0.21^{\mathrm{a}}$ & $43.0 \pm 1.9^{\mathrm{b}}$ & $2.60 \pm 0.10^{\mathrm{b}}$ & $177.5 \pm 7.6^{\mathrm{b}}$ & $97.9 \pm 3.4^{\mathrm{a}}$ \\
$3.5 \%$ His $+0.5 \%$ Met & $32.8 \pm 2.5^{\mathrm{b}}$ & $5.60 \pm 0.18^{\mathrm{a}}$ & $47.2 \pm 2.2^{\mathrm{ab}}$ & $2.54 \pm 0.12^{\mathrm{b}}$ & $198.7 \pm 13.0^{\mathrm{ab}}$ & $107.8 \pm 8.1^{\mathrm{a}}$ \\
$3.5 \%$ His $+1.0^{\mathrm{a}} \% \mathrm{Met}$ & $22.4 \pm 1.2^{\mathrm{c}}$ & $5.33 \pm 0.20^{\mathrm{a}}$ & $51.9 \pm 2.7^{\mathrm{a}}$ & $2.60 \pm 0.06^{\mathrm{b}}$ & $213.7 \pm 6.2^{\mathrm{a}}$ & $109.7 \pm 4.3^{\mathrm{a}}$ \\
\hline
\end{tabular}

Average initial body weight of rats, $88 \mathrm{~g}$.

Mean \pm SEM for 5 rats.

3 Means within the same column with different superscripts are significantly different $(p<0.05)$ by Duncan's multiple range test.

* Significantly different from a basal diet $(p<0.05)$ by Student's $t$-test.

Table III. Effect of the Addition of Taurine or Cystine to a Basal or a $3.5 \%$ Histidine Diet on Body Weight Gain, Liver Weight, Total Liver Lipids, Liver Cholesterol, Serum Total and HDL Cholesterol in Rats (Experiment 2) ${ }^{1}$

\begin{tabular}{ccccccc}
\hline Diet & $\begin{array}{c}\text { Body weight } \\
\text { gain } \\
(\mathrm{g} / 10 \text { days })\end{array}$ & $\begin{array}{c}\text { Liver weight } \\
(\mathrm{g} / 100 \mathrm{~g} \mathrm{BW})\end{array}$ & $\begin{array}{c}\text { Total liver } \\
\text { lipids } \\
(\mathrm{mg} / \mathrm{g})\end{array}$ & $\begin{array}{c}\text { Liver } \\
\text { cholesterol } \\
(\mathrm{mg} / \mathrm{g})\end{array}$ & $\begin{array}{c}\text { Serum total } \\
\text { cholesterol } \\
(\mathrm{mg} / 100 \mathrm{ml})\end{array}$ & $\begin{array}{c}\text { Serum HDL } \\
\text { cholesterol } \\
(\mathrm{mg} / 100 \mathrm{ml})\end{array}$ \\
\hline Basal & $39.3 \pm 2.5^{2}$ & $4.87 \pm 0.11$ & $56.2 \pm 3.8$ & $2.77 \pm 0.05$ & $118.6 \pm 5.0$ & $61.7 \pm 3.0$ \\
Basal $+5.0 \%$ Tau & $42.1 \pm 2.6$ & $5.01 \pm 0.09$ & $57.0 \pm 1.8$ & $2.56 \pm 0.04^{*}$ & $121.2 \pm 3.1$ & $69.8 \pm 3.3$ \\
Basal+1.0\% Cys & $40.1 \pm 3.0$ & $5.41 \pm 0.09^{*}$ & $57.2 \pm 1.7$ & $2.54 \pm 0.05^{*}$ & $123.3 \pm 2.2$ & $69.5 \pm 2.9$ \\
\hline Basal & $45.5 \pm 2.7^{\mathrm{a} 3}$ & $5.17 \pm 0.11^{\mathrm{b}}$ & $60.4 \pm 5.8^{\mathrm{a}}$ & $4.10 \pm 0.13^{\mathrm{a}}$ & $113.0 \pm 2.6^{\mathrm{c}}$ & $66.9 \pm 2.6^{\mathrm{b}}$ \\
$3.5 \% \mathrm{His}$ & $38.5 \pm 2.1^{\mathrm{abc}}$ & $6.89 \pm 0.26^{\mathrm{a}}$ & $39.4 \pm 2.6^{\mathrm{b}}$ & $3.66 \pm 0.19^{\mathrm{ab}}$ & $145.8 \pm 3.4^{\mathrm{b}}$ & $90.8 \pm 4.7^{\mathrm{a}}$ \\
$3.5 \% \mathrm{His}+1.0 \%$ Tau & $41.6 \pm 2.8^{\mathrm{ab}}$ & $6.42 \pm 0.30^{\mathrm{a}}$ & $46.0 \pm 4.7^{\mathrm{b}}$ & $3.98 \pm 0.18^{\mathrm{ab}}$ & $147.6 \pm 4.7^{\mathrm{ab}}$ & $97.0 \pm 4.2^{\mathrm{a}}$ \\
$3.5 \% \mathrm{His}+2.5 \%$ Tau & $39.1 \pm 3.1^{\mathrm{abc}}$ & $6.82 \pm 0.27^{\mathrm{a}}$ & $45.2 \pm 4.9^{\mathrm{b}}$ & $3.70 \pm 0.18^{\mathrm{ab}}$ & $149.6 \pm 4.1^{\mathrm{ab}}$ & $98.0 \pm 7.1^{\mathrm{a}}$ \\
$3.5 \% \mathrm{His}+5.0 \%$ Tau & $35.8 \pm 2.3^{\mathrm{bc}}$ & $6.80 \pm 0.34^{\mathrm{a}}$ & $35.5 \pm 1.5^{\mathrm{b}}$ & $3.26 \pm 0.06^{\mathrm{b}}$ & $137.8 \pm 3.2^{\mathrm{b}}$ & $84.5 \pm 5.4^{\mathrm{a}}$ \\
$3.5 \% \mathrm{His}+0.5 \%$ Cys & $33.7 \pm 1.6^{\mathrm{c}}$ & $7.12 \pm 0.37^{\mathrm{a}}$ & $36.3 \pm 2.9^{\mathrm{b}}$ & $3.28 \pm 0.09^{\mathrm{b}}$ & $146.0 \pm 3.5^{\mathrm{b}}$ & $89.4 \pm 6.3^{\mathrm{a}}$ \\
$3.5 \% \mathrm{His}+1.0 \%$ Cys & $34.3 \pm 0.7^{\mathrm{bc}}$ & $6.68 \pm 0.21^{\mathrm{a}}$ & $35.8 \pm 2.3^{\mathrm{b}}$ & $3.37 \pm 0.02^{\mathrm{b}}$ & $159.0 \pm 4.6^{\mathrm{a}}$ & $92.3 \pm 1.5^{\mathrm{a}}$ \\
\hline
\end{tabular}

1 Average initial body weight of rats, $107 \mathrm{~g}$.

2 Mean \pm SEM for 5 rats.

3 Means within the same column with different superscripts are significantly different $(p<0.05)$ by Duncan's multiple range test.

* Significantly different from a basal diet $(p<0.05)$ by Student's $t$-test.

$3.5 \%$ histidine diet caused a further increase in the serum cholesterol level.

\section{Experiment 3}

The effect of glycine addition to the $3.5 \%$ histidine diet on body weight gain, liver weight, and on the levels of total liver lipids, liver cholesterol, serum total cholesterol and serum HDL-cholesterol in the rats is summarized in Table IV. The addition of glycine to the basal diet did not cause significant changes in body weight gain, liver weight and liver and serum lipids levels, except for liver cholesterol level. The body weight gain in rats fed with the $3.5 \%$ histidine diet was significantly lower than that in rats fed with the 
Table IV. Effect of the Addition of Glycine to a Basal Diet or a $3.5 \%$ Histidine Diet on Body Weight Gain, Liver Weight, Total Liver Lipids, Liver Cholesterol, Serum Total and HDL Cholesterol in Rats (Experiment 3) ${ }^{1}$

\begin{tabular}{ccccccc}
\hline Diet & $\begin{array}{c}\text { Body weight } \\
\text { gain } \\
(\mathrm{g} / 10 \text { days })\end{array}$ & $\begin{array}{c}\text { Liver weight } \\
(\mathrm{g} / 100 \mathrm{~g} \mathrm{BW})\end{array}$ & $\begin{array}{c}\text { Total liver } \\
\text { lipids } \\
(\mathrm{mg} / \mathrm{g})\end{array}$ & $\begin{array}{c}\text { Liver } \\
\text { cholesterol } \\
(\mathrm{mg} / \mathrm{g})\end{array}$ & $\begin{array}{c}\text { Serum total } \\
\text { cholesterol } \\
(\mathrm{mg} / 100 \mathrm{ml})\end{array}$ & $\begin{array}{c}\text { Serum HDL } \\
\text { cholesterol } \\
(\mathrm{mg} / 100 \mathrm{ml})\end{array}$ \\
\hline $\begin{array}{c}\text { Basal } \\
\text { Basal }+5.0 \% \text { Gly }\end{array}$ & $39.3 \pm 2.5^{2}$ & $4.87 \pm 0.11$ & $56.2 \pm 3.8$ & $2.77 \pm 0.05$ & $118.6 \pm 5.0$ & $61.7 \pm 3.0$ \\
\hline Basal & $45.6 \pm 5.0$ & $5.01 \pm 0.19$ & $52.8 \pm 1.9$ & $2.53 \pm 0.07^{*}$ & $107.5 \pm 4.0$ & $60.4 \pm 3.7$ \\
$3.5 \%$ His & $45.8 \pm 1.3^{\mathrm{a} 3}$ & $5.04 \pm 0.11^{\mathrm{b}}$ & $50.3 \pm 2.4^{\mathrm{a}}$ & $3.30 \pm 0.09$ & $128.9 \pm 6.8^{\mathrm{c}}$ & $76.5 \pm 5.2^{\mathrm{c}}$ \\
$3.5 \%$ His $+1.0 \%$ Gly & $39.1 \pm 1.1^{\mathrm{ab}}$ & $7.39 \pm 0.22^{\mathrm{a}}$ & $40.7 \pm 0.5^{\mathrm{b}}$ & $3.10 \pm 0.05$ & $192.9 \pm 8.1^{\mathrm{b}}$ & $126.6 \pm 6.0^{\mathrm{ab}}$ \\
$3.5 \%$ His $+2.5 \%$ Gly & $34.8 \pm 3.9^{\mathrm{b}}$ & $7.01 \pm 0.36^{\mathrm{a}}$ & $42.5 \pm 1.3^{\mathrm{b}}$ & $3.27 \pm 0.05$ & $175.3 \pm 2.0^{\mathrm{b}}$ & $114.7 \pm 4.9^{\mathrm{b}}$ \\
$3.5 \%$ His $+5.0 \%$ Gly & $38.0 \pm 2.8^{\mathrm{ab}}$ & $7.35 \pm 0.44^{\mathrm{a}}$ & $40.3 \pm 2.3^{\mathrm{b}}$ & $3.09 \pm 0.10$ & $178.7 \pm 4.4^{\mathrm{b}}$ & $117.5 \pm 2.9^{\mathrm{b}}$ \\
\hline
\end{tabular}

1 Average initial body weight of rats, $91 \mathrm{~g}$.

2 Mean \pm SEM for 5 rats.

3 Means within the same column with different superscripts are significantly different $(p<0.05)$ by Duncan's multiple range test.

* Significantly different from a basal diet $(p<0.05)$ by Student's $t$-test.

basal diet, although the addition of glycine did not cause any further changes in body weight gain. The liver weight in rats fed with the $3.5 \%$ histidine diet was significantly higher than in rats fed with the basal diet, although the addition of glycine to the 3.5\% histidine diet did not cause any significant change in liver weight. The total liver lipids content in rats fed with the $3.5 \%$ histidine diet was similar to that in rats fed with the basal diet. The total liver lipids content was significantly decreased by the addition of glycine as compared with that in rats fed with the basal diet, but not significantly when compared with that in rats fed with the $3.5 \%$ histidine diet. The liver cholesterol content in rats fed with the $3.5 \%$ histidine diet with or without glycine was not significantly different as compared with that in rats fed with the basal diet. Serum total cholesterol and HDLcholesterol levels in rats fed with the $3.5 \%$ histidine diet were significantly higher than those in rats fed with the basal diet, were decreased by the addition of $2.5 \%$ or $5.0 \%$ glycine, but were not affected by $1.0 \%$ glycine.

\section{DISCUSSION}

It has been reported that dietary supplemen- tation with excess L-histidine lead to growth retardation, hepatomegaly and increased plasma cholesterol in rats. ${ }^{47}$ Although rats did not ingest much cholesterol in the histidine-fed group, serum cholesterol has shown a significant increase. ${ }^{4,5)}$ The mechanism for the increase in serum cholesterol has been investigated, Solomon and Geison ${ }^{6)}$ reporting that the histidine-excess diet caused a 100\% increase in the incorporation of $\left.{ }^{14} \mathrm{C}\right]$ acetate or $\left[{ }^{14} \mathrm{C}\right]$ octanoate into cholesterol by liver slices from weanling rats. Qureshi et al. ${ }^{7)}$ have also reported that the incorporation of $\left[{ }^{14} \mathrm{C}\right]$ acetate or $\left[{ }^{14} \mathrm{C}\right]$ mevalonate into cholesterol was significantly higher in a $5000 \times g$ liver supernatant fraction of histidine-supplemented chow-fed rats as compared with the control.

In the present study, we used histidineinduced hypercholesterolemia as a model for endogenous hypercholesterolemia to examine the effect of adding taurine, cystine, methionine or glycine on serum and liver cholesterol levels. We also examined the effect of adding these amino acids to the basal diet, which did not cause any change in the serum total cholesterol level. The significant effect of these amino acids on serum cholesterol was revealed when they were added to the $3.5 \%$ 
histidine diet fed to the rats.

Taurine is known to have had a hypocholesterolemic effect on cholesterol-fed mice and rats. ${ }^{1,2)}$ The mechanism for the reduction in serum cholesterol level by taurine is thought to increase the taurine-conjugated bile acids ${ }^{14}$ ) and accelerate their fecal excretion. ${ }^{15}$ ) Our results show that the addition of taurine, even at a $5 \%$ level, caused no significant decrease in serum cholesterol. The effect of taurine on the serum cholesterol level may be variable in response to the cause of hypercholesterolemia. It thus appears that taurine is effective in preventing the hypercholesterolemia that is induced by dietary cholesterol, but is ineffective in preventing the hypercholesterolemia that is induced by excess histidine.

Methionine and cystine are precursor amino acids to taurine, ${ }^{8)}$ but we observed that the effect of these amino acids on the serum cholesterol level was different from that of taurine (Tables II and III). In a cholesterolsupplemented diet with a standard protein level $(25 \%$ casein $)$, cystine has shown a hypocholesterolemic effect, while methionine caused a further increase in serum cholesterol. $^{16)}$ Cystine added to a cholesterol-free diet at a standard protein level has caused hypercholesterolemia. ${ }^{17)}$ On the other hand, Yagasaki et al. reported that the addition of cystine $(0.6$ to $2.4 \%)$ to a $20 \%$ casein diet caused no change in serum cholesterol. ${ }^{18)}$ Their results also suggested that the addition of methionine at a $2.4 \%$ level caused a decrease in serum cholesterol in rats fed with a $20 \%$ casein diet, but the addition of methionine caused no significant decrease at a lower level $(0.6$ or $1.2 \%)$. However Nagaoka et $a l .{ }^{19)}$ reported that the addition of methionine at a $0.75 \%$ level caused an increase in serum cholesterol in rats fed with a $20 \%$ casein diet, but showed only an increasing tendency at the $1.5 \%$ level. In the present study, both cystine and methionine caused a further increase in serum cholesterol in the $3.5 \%$ histidine diet (Tables II and III). These results suggest that the effect of methionine or cystine on serum cholesterol may vary with the dietary con- ditions and with their levels of addition.

On the other hand, liver cholesterol was decreased by the addition of taurine, cystine or methionine in rats fed with cholesterolsupplemented diets. ${ }^{16)}$ In rats fed with a cholesterol-free diet, the addition of cystine at the $5 \%$ level caused a decrease in liver cholesterol, ${ }^{17)}$ while an addition at the 0.6 to $2.4 \%$ level of cystine or methionine had no effect on liver cholesterol. ${ }^{18)}$ In the presernt study, the addition of taurine, cystine or glycine to the basal diet caused a decrease in liver cholesterol, but the addition of each of these amino acids to the histidine-excess diet had no significant effect on liver cholesterol. However the dietary addition of taurine, cystine or methionine has reduced liver cholesterol in rats fed with a cholesterol diet. ${ }^{16)}$ As the liver cholesterol level in rats fed with the 3.5\% histidine diet was lower than that in rats fed with the cholesterol diet, it may be difficult to cause any further decrease in liver cholesterol in rats fed with the $3.5 \%$ histidine diet by the addition of taurine, cystine or glycine.

Based on the previous reports, the addition of glycine to a cholesterol-supplemented $\operatorname{diet}^{20)}$ or to a cholesterol-free casein $\operatorname{diet}^{3)}$ caused a decrease in the serum cholesterol level. In the present study, although the addition of glycine to the basal diet showed only a decreasing tendency in serum cholesterol, the addition of glycine to the $3.5 \%$ histidine diet caused a significant decrease in serum cholesterol without affecting the body weight gain (Table IV). The effect of glycine on the serum cholesterol level may occur regardless of the presence of dietary cholesterol. It has also been reported that glycine added to a cholesterolsupplemented diet decreased liver cholesterol as well as serum cholesterol. ${ }^{20}$ ) the present study shows that liver cholesterol in rats fed with the $3.5 \%$ histidine diet was not affected by the addition of glycine (Table IV). The mechanism by which glycine decreases the serum and/or liver cholesterol levels is still unknown. In rats, glycine-conjugated bile acids rarely occur, but bilt acids are mostly conjugated with taurine. ${ }^{21)}$ Therefore, even though. 
glycine-conjugated bile acids can be increased by the addition of glycine, the stimulated excretion of glycine-conjugated bile acids may contribute little to the decrease observed in serum cholesterol level.

\section{REFERENCES}

1) E. E. Howe and D. K. Bosshardt, J. Nutr., 76, 242 (1962).

2) K. Tsuji, R. Kawamura and Y. Nakagawa, Sulfur Amino Acids, 5, 147 (1982).

3) M. B. Katan, L. H. M. Vroomen and R. J. J. Hermus, Atherosclerosis, 43, 381 (1982).

4) Y. Aoyama, E. Ohmura, A. Yoshida and K. Ashida, Agric. Biol. Chem., 49, 621 (1985).

5) E. Ohmura, Y. Aoyama and A. Yoshida, Lipids, 21, 748 (1986).

6) J. K. Solomon and R. L. Geison, Proc. Soc. Exp. Biol. Med., 159, 44 (1978).

7) A. A. Qureshi, J. K. Solomon and B. Eichelman, Proc. Soc. Exp. Biol. Med., 159, 57 (1978).

8) K. C. Hayes, Ann. Rev. Nutr., 1, 401 (1981).

9) J. Folch, M. Lees and G. H. Sloane Stanley, J. Biol. Chem., 226, 497 (1957).
10) A. Zlatkis and B. Zak, Anal. Biochem., 29, 143 (1969).

11) A. Noma, K. Nezu-Nakamura, M. Kita and H. Okabe, Clin. Chem., 24, 1504 (1978).

12) D. B. Duncan, Biometrics, 13, 164 (1957).

13) G. W. Snedecor and W. G. Cochran, "Statistical Methods," 6th Ed., The Iowa State University Press, Ames, IA, 1967, (Japanese translated edition, Iwanami Pub. Inc., Tokyo, pp. 87 114).

14) A. Kibe, C. Wake, J. Kuramato and T. Hoshita, Lipids, 15, 224 (1980).

15) Y. Yamanaka, K. Tsuji, T. Ichikawa, Y. Nakayama and M. Kawamura, Sulfur Amino Acids, 7, 257 (1984).

16) K. Sugiyama, Y. Kushima and K. Muramatsu, Agric. Biol. Chem., 48, 2897 (1984).

17) A. Rukaj and C. Serougne, Biochim. Biophys. Acta, 753, 1 (1983).

18) K. Yagasaki, T. Aoki and R. Funabiki, Nutr. Rep. Int., 34, 59 (1986).

19) S. Nagaoka, Y. Aoyama and A. Yoshida, Nutr. Rep. Int., 31, 1137 (1985).

20) K. Sugiyama, Y. Kushima and K. Muramatsu, Agric. Biol. Chem., 49, 3455 (1985).

21) D. G. Spaeth and D. L. Schneider, Proc. Soc. Exp. Biol. Med., 147, 855 (1974). 